Volume 5 Issue 1, March 2021

sisaddergi@gmail.com

Makale Türü/Article Type: Araştırma/Research

Makale Gönderim Tarihi/Received Date: 17.03.2021

Makale Kabul Tarihi/Accepted Date: 26.03.2021

DOI: $10.30692 /$ sisad. 898583

\title{
ESKİ ANADOLU TÜRKÇESİ BAĞLAMINDA "OHT" SÖZCÜĞÜ*
}

\section{The Word "Oht" In The Context of Old Anatolian Turkish}

\author{
Himmet BÜKE \\ Doç. Dr. \\ Mehmet Akif Ersoy Üniversitesi \\ Fen Edebiyat Fakültesi, Türk Dili ve Edebiyatı Bölümü \\ ORCID ID: 0000-0002-6768-5396 \\ himmetbuke@mehmetakif.edu.tr
}

Atıf/Citation: Himmet Büke (2021), "Eski Anadolu Türkçesi Bağlamında "Oht" Sözcügü̈, Stratejik ve Sosyal Araştırmalar Dergisi, C.5, S.1 Mart 2021 s.171-180.

\begin{abstract}
Öz: Eski Anadolu Türkçesi, XI. yüzyılda Oğuz Türklerinin Anadolu coğrafyasına göçleriyle başlayan süreçte oluşan ve daha sonraki yüzyıllarda Batı Türkçesinin temelini teşkil edecek olan yazı dilinin adıdır. Bu dönem Osmanlı Türkçesi dönemiyle devam ederek bugün resmî konuşma ve yazı dilimiz olan Türkiye Türkçesinin de temelini oluşturur. Selçukluların Anadolu coğrafyasına girişiyle yoğun bir Türk nüfusu fethedilen bölgelere yerleşmiş bununla beraber Türkçenin bu yeni coğrafyada konuşma ve yazı dili olma süreci başlamıştır. Türkçenin Anadolu'daki bu ilk yıllarına ait bugüne ulaşabilmiş yazılı eser sayısı oldukça sınırlıdır. Bunda Selçuklu Devleti'nin Türkçeyi devlet ve bürokrasi dili olarak kullanmaması, Arapça ve Farsçanın ulema ve devlet adamları tarafindan tercih edilmesi etkilidir. Eski Anadolu Türkçesi verimli ve en güçlü dönemini Selçuklu Devleti sonrası Anadolu coğrafyasının farklı bölgelerinde kurulmuş olan beylikler zamanında yaşamıştır. Beylikler döneminde Anadolu'nun farklı şehirleri beylik merkezleri olmuş ve bu merkezlerde Türkçenin Anadolu sahasındaki önemli ve çok kıymetli eserleri verilmiştir. Anadolu'da Türkçenin yazı dili olma süreci bu dönemde önemli ölçüde mesafe kat etmiştir. Bugün bu dönemden kalan eserlerin hemen hemen hepsi incelenmiş haklarında pek çok ilmî çalışma yapılmıştır. Dönemin sözvarlığı çeşitli sözlüklerde ve incelenen eserlerin dizin bölümlerinde ortaya konulmuş yine dönemin gramer özellikleri büyük ölçüde tespit edilmiștir. Fakat dönemin sözvarlığı içerisinde üzerinde tekrar durulması, müstakil çalıșmalar yapılması gereken pek çok sözcük bulunmakta bu sözcüklerin Eski Türkçe, Orta Türkçe ve günümüz lehçelerindeki görünümlerine bakılması gerekmektedir. Sadece bir eserde tespit edilen hapaksları da bu tür derinlemesine çalışmalarla yeniden anlamlandırma imkanı ortaya çıkacaktır. Bu çalışmada sadece Eski Anadolu Türkçesi dönemi eserlerinde kullanılmış olan "oht” sözcüğü ele alınacaktır. Bu sözcük Türkçenin başka dönemlerinde yazılan eserlerde tespit edilmemiş olup sadece Eski Anadolu Türkçesine mahsus bir kullanımdır. Sözcük hakkındaki genel görüş; Arapça "vakt" sözcüğüyle ilgili olduğudur. Bu sözcüğün Türkçeye girdikten sonra fonetik değişikliğe uğradığı ve bir söyleyiş biçimi kazandığı düşünülse de konuyla ilgili farklı tespitleri verecek bu sözcügü tartışmaya açacağız. Sözcügün Türkçe kökenli mi yoksa yabancı menşeili mi olduğu üzerinden giderek tarihsel sürece ve sözcügün kullanım alanlarına bir yorum getirmeye çalışacağız. Yazılı kaynakların tanıklığının yanı sıra sözcüğün Anadolu ağızlarındaki kullanımı da değineceğiz. Bu konuda Anadolu ağızlarının ciddi bir belirleyici olduğunu düşünmekle beraber Türkçenin farklı lehçelerindeki tarihi
\end{abstract}

\footnotetext{
* Bu çalışma 11. Uluslararası Dünya Dili Türkçe Sempozyumu'nda “Eski Anadolu Türkçesi Bağlamında “oht” Sözcüğü Üzerine" adıyla sunulan sözlü bildirinin genişletilmiş biçimidir.
} 
metinler ele alınıp bu sözcüğün veya bu sözcükle bağlantılı olduğu düşünülen sözcüklerin köken ve bağlamları ortaya konulacaktır.

Anahtar Kelimeler : oht, vakit, Eski Anadolu Türkçesi, olok, şolok

\begin{abstract}
Ancient Anatolian Turkish is the name of the literary language that formed in the process that began with the migration of Oghuz Turks to Anatolian geography in the XI century and will form the basis of Western Turkish in the following centuries. This period continuing with the Ottoman Turkish period creates the basis of Turkey Turkish, which is the official spoken and written language today. With the introduction of Seljuks to Anatolian geography, a large Turkish population settled in the conquered regions, and with this, Turkish has started to become the language of speech and writing in this new geography. The number of written works that have survived to this day from these early years of Turkish in Anatolia is quite limited. In this case, the fact that the Seljuk State didn't use Turkish as the language of state and bureaucracy and that Arabic and Persian were preferred by science people and statesmen is quite effective. The productive and most powerful period for the old Anatolian Turkish was the period of the principalities established in different regions of Anatolian geography after the Seljuk State During the principality period, different cities of Anatolia became principality centers, and the important and very valuable works of Turkish in the Anatolian area were produced in these centers. The process of becoming the written language of Turkish in Anatolia has come a long way in this period. Today, almost all of the works from this period have been examined and many scientific studies have been carried out. The vocabulary in this period has been revealed in various dictionaries and index sections of the studied works, again, the grammatical features of the period have been identified to a great extent. However, there are many words in the vocabulary of the period that need to be dwelled on again and to be studied individually. It is necessary to look at the appearance of these words in Old Turkish, Middle Turkish and in today's dialects. With such in-depth studies, it will be possible to reinterpret the hapaxes detected in only one work. In this study, the word "oht" used only in the works of the Old Anatolian Turkish period will be discussed. This word has not been detected in the works written in any other periods of Turkish and is used exclusively in the Old Anatolian Turkish. The general view about the word is that it is related to the Arabic word "vakt (time)". Although it is thought that this word has undergone a phonetic change after entering Turkish and has acquired a new phraseology, we will open this word to discussion to give different verdicts on the subject. We will try to make an interpretation of the historical process and the usage areas of the word by considering whether the word is of Turkish origin or foreign origin. In addition to the testimony of written sources, we will also mention the use of the word in Anatolian dialects. Although we think that Anatolian dialects are a serious determinant in this issue, historical texts in different dialects of Turkish will be discussed and the origins and contexts of this word or the words that are thought to be related to this word will be revealed.
\end{abstract}

Keywords : oht, time, Old Anatolian Turkish, olok, solok

\title{
GíRiş
}

Türkçenin Anadolu sahasında bir yazı dili haline geldiği Eski Anadolu Türkçesi dönemi bugünkü Türkiye Türkçesinin de temellerini oluşturmaktadır. Bu yazı dilinin oluşma süreci Türk milletinin siyasi ve kültürel pozisyonuyla doğrudan bağlantılı olup pek çok farklı etkenin dil üzerinde etkili olduğu bir dönemdir. Selçukluların XI. yüzyılda Anadolu topraklarına girmesiyle başlayan bu süreçte Horasan ve Maveraünnehir gibi Oğuz nüfusun yoğun olduğu bölgelerden başlayan ve yüzyıllarca sürecek göç dalgası başat etken olmuştur. Türkistan coğrafyasındaki Türklerin bu yeni vatana göçleriyle Türkçenin de yeni bir vatana sahip olma serüveni başlamıştır. Anadolu'da oluşan bu yeni yazı dili, yerli Oğuz ağızları ile Türkistan'daki yazılı ve sözlü Türkçe geleneğine dayanmaktadır (Akar, 2018, s. 18). Oğuzların göçleriyle Türk nüfusu oluşmayan başlayan Anadolu bu yüzyıllarda siyasî, kültürel, dinî ve ekonomik olarak istikrarsız ve kaotik bir süreci de beraberinde yaşamıştır. Türklerin hem Bizans hem de Moğollarla mücadelesi Anadolu'daki siyasî otoritenin sağlam bir şekilde kurulamaması gibi bir sorunu meydana getirmiştir. Diğer taraftan Selçuklular devrinde devlet dili olamama gibi büyük bir badireyi atlatan Türkçe, Beylikler Döneminde kendini göstermeye başlamış ve nihayet Osmanlı Devleti'nin teşekkül etmesiyle devlet dili haline gelebilmiştir.

Anadolu'da vücut bulan bu yazı dili Türkçenin zengin söz varlığını devam ettirmiş, Arapça ve Farsça gibi dillerin etkisine de maruz kalmıştır. Anadolu'da Arapça ve Farsça ile bir müddet mücadele eden Oğuzca, XIII. yüzyıldan günümüze kadar kesintisiz olarak edebi yazı dili olarak ürünler vermiştir (Gülsevin ve Boz, 2010, s. 4). Özellikle Beylikler Dönemi bu anlamda en verimli ve Anadolu'da teşekkül eden Türkçenin en güçlü ilk dönemidir. Bu dönemde Türkçe tam anlamıyla bir yazı dili olma sürecine girmiş ve yazılan bir çok tercüme ve telif eserle Türkçenin güçlü söz varllğı ortaya konulabilmiştir. Türkçenin daha çok bir konuşma dili olarak kaldığı ilk 
döneme göre Beylikler Dönemi gerek dil gerekse kültür tarihimiz açısından çok kritik bir dönüm noktası olarak değerlendirilebilir. Türkmen beylerinin kendi dilleriyle söz söyleyecek yazar ve şairleri desteklemeleri ve onlara imkân hazırlamalarıyla, Türk kültürü lehine gerçek bir değişim yaşanmıştır (Cahen, 1994, s. 347). Arapça ve Farsçanın gölgesinde kalan Türkçe Anadolu'daki beylik merkezlerinde yeniden hak ettiği konuma gelmiş, tercüme eserlerle bu dillerdeki söz varlığını karşılayabildiğini, telif eserlerle de ne kadar güçlü bir dil olduğunu göstermiştir. Zengin bir söz varlığına sahip olan bu dönem Türkçesiyle tefsir, hadis, menkıbe, dinî kıssalar gibi Arapça ve mesnevî türündeki Farsça eserler oldukça güzel ve anlaş1ır bir şekilde yazılmıştır (Canpolat, 1988).

\section{OHT SÖZCÜĞÜ ÜZERINE}

Eski Anadolu Türkçesi döneminin söz varlığı bugün elde bulunan eserlerden hareketle kısmen de olsa ortaya konulmuştur. Zengin bir sözcük çeşitliği barındıran bu döneme ait bazı sözcükler hakkında farklı görüşler bulunmaktadır. Bazı sözcüklerin tek bir eserde geçiyor olması hem okuma hem de anlamlandırma bakımından birtakım güçlükleri de beraberinde getirmektedir. Diğer taraftan bazı sözcüklerin de kökenleri veya etimolojik izahları bakımından bazı görüş farklılıkları bulunmaktadır. Bu çalışmada sadece Eski Anadolu Türkçesi dönemi yazılı eserlerinde görülen ve daha sonraki dönemlerde rastlanmayan "oht" sözcüğü üzerinde durulacaktır. Sözcük dönem eserlerinde "okt, oht, ok" gibi farklı şekillerde kullanılmış olup sözcügün kökeni hakkında görüş bildiren çalışma sayısı çok azdır. Sözcük üzerinde bugüne kadar sadece bir çalışma yapılmış olup bu çalışmada sözcüğün anlamı ve kökeni üzerine bazı görüşler belirtilmiştir.

“Oht” sözcüğü için Tarama Sözlüğünde; vakit, çağ (160); Eski Anadolu Türkçesi Sözlüğünde; vakit, zaman, çağ (531) gibi anlamlar verilmektedir. Sözcügün kullanıldığı beyitlerin bağlam özellikleri göz önüne alındığında "zaman, vakit, an" anlamında kullanıldığı bazen ad ama daha çok zaman bildiren bir zarf görevinde olduğu görülmektedir. Sözcügün kökeninin belirsizliğiyle birlikte sadece Türkçenin bir döneminde görülüp öncesi ve sonrasındaki yazılı metinlerde görülmemesi yönüyle de ilginçtir. Eski Anadolu Türkçesinin günümüze ulaşan eserlerinde sözcüğün kullanımları şu şekildedir ${ }^{1}$ :

$$
\text { oht (اخت ) }
$$

gözedürdi nakkaş ol oht olıcak

ki karanulıh toldı her bir bucak (SN/1724)

süheyl eydür ohtı degül ol sözün

başunuzı agrıdısarvan sizün (SN/1815)

kişi kim süci içmek ohtın öner

gönül hoşlugile içerse siner (SN/4646)

ol ohtun olasin aziz u ulu

ki sen kendözüñi göresin alu (FN/539)

\footnotetext{
${ }^{1}$ Süheyl ü Nevbahar ve Ferhengname dışındaki örnekler Tarama Sözlügünden alınmıştır.
} 
sikender ki kafdan kafa itdi hükm

şol oht oldı kim gitmege yitdi hükm (FN/1002)

son ohtın kim cihandan gidiserven

tapusunu veliaht ediserven (HN/71)

beş ohtun vaktına daimler içün

fariza üzre hem kaimler içün (IN/326-1)

okt (اوقت):

bigah [Fa.] : oktsuz اوقتسز (ŞL/220)

\section{ok (olok/şolok):}

nereye kim varam başlar kesilür

kime buşar isem olok dem (اولقدم) ölür (YED/16)

olok dem kim ol dama ağmış idi

sanasın güneş dünle doğmuşidi (SN/9)

Şeytan elin küpe sokar olok saat (ساعة الق) süci kaynar. (KG/87)

olok saat (ساعت اولق) firdevs uçmağında bulunduk. (RE/30)

mescid-i aksaya çünkim vardılar

dünya göğüne şolok dem (دمثثلق) irdiler (MŞ/7-2)

meğer kapıcılar anı görürler

şolok dem hatuna haber verirler (DAH/76)

şolok saat (ساعت شثلق) halife destur verdi. (TET/7-1)

ol ağu temamet ol avratın boğuzuna gitti, şolok saat avrat helak oldu (KD/18)

Bu dönem metinlerinde "oht” sözcüğünün pek çok örnekte kullanıldığı görülüyor. Burada sadece bir kısmını verdiğimiz örnekler dönem eserlerinde tespit edilebilir ve sayısı arttırılabilir. Görüldüğü üzere sözcüğün üç farklı kullanımı tespit edilmiştir; sözcük "oht, okt ve ok" biçimlerinde kullanılmıştır. Bu farklı kullanımlarla ilgili dönemsel bir belirleyicilikten söz edilmesi mümkün görünmemektedir. Yani sözcüğün hangi kullanımının daha eskicil olduğunu 
belirlemek güçtür çünkü aynı dönem eserlerinde ve hatta aynı eser içinde sözcügün farklı kullanım biçimleri mevcuttur. Mesela 14.yüzyıl eseri olan Süheyl ü Nevbahar'da hem "oht”, hem de "olok" şekli kullanılmıştır. Dolayısıyla bu durum sözcüğün fonetik olarak tam bir biçime oturmadığını ya da bunların farklı kökenlerden gelen ayrı ayrı sözcükler olduğu ihtimalini düşündürmektedir.

“Oht” sözcügünün köken ve yapısıyla ilgili olası durumları değerlendirmek sözcük hakkında daha sağlıklı yorum yapabilmek adına faydalı olacaktır. Burada sözcüğün kökeninin Türkçe mi yoksa başka bir ile mi ilişkili olduğu hususunda bazı görüşler ortaya konulacaktır:

\section{Sözcüğün Arapça "vakt” Sözcüğüyle İlgisi}

"oht” sözcüğünün "zaman, vakit" anlamında kullanılması, "okt/oht” gibi biçimlerin Eski Türkçe, Orta Türkçe gibi dönemlerde görülmemesi, konsonant ve vokal dizilimi açısından Türkçenin kurallarına uymaması sözcüğün aslında yabancı kökenli bir sözcük olup birtakım fonetik değişikliklerle bu hale geldiği olasılığını düşündürmektedir. Yine bu sözcük pek çok metinde "oht/vakt vaht" uyağıyla kullanılmıştır. Öyle anlaş1lıyor ki "oht /ol ohtın /ohtın" gibi kullanışların nerden geldiği konusunda düşünen yazarlar, bunun vakt'ın bozulmuş biçimi olduğunu düşünmüşler ve doğru biçimi kullanmak istemişler (Canpolat, 1988, s.179). Sözcügün fonetik olarak: vakt $>$ vaht $>$ voht $>$ oht $>$ oğ $>$ ot $>$ ut gibi bir değişime uğradığı düşünülebilir. Anadolu ağızlarından tespit ettiğimiz: aşamoğtu (K.Maraş, aşamotu (Adana-Çukurova-Kozan), aşamutu, geceoğtu (K.Maraş), ağşamın ohtu gicenin ohtu (Konya-Kadınhanı), onun üzerinden ohtu zaman geçmiş gecenin bir ohtusu olmuş (A.Karahisar-Dazkırı) gibi kullanımlar ve Derleme Sözlüğünde Aydın-Bozdoğan, Gaziantep, Muğla-Ulada, Manisa-Alaşehir bölgelerinde kullanılan (DS, 3275) "oht,ohtu" sözcükleri Eski Anadolu Türkçesi dönemindeki kullanımların aynen ya da değişerek kullanıldığını göstermektedir.

Fakat şunu da belirtmek gerekir ki bu dönem metinlerinde "vakit, vakıt, vakt, vaht" gibi sözcükler de sıkça görülmektedir. Hatta Işkname'de geçen:

"beş ohtun vaktına daimler içün

fariza üzre hem kaimler içün” (IN/326-1)

beytinde "oht" ve "vakt" sözcüklerinin yan yana kullanıldığı görülür. Bu durum da bu iki sözcük arasında fonetik bir değişimden ziyade ince bir anlam farklıllı̆ı olduğunu düşündürmektedir. Diğer taraftan sözcügün Codex Cumanicus'ta yer alması sözcükle ilgili Kıpçak sahasına da bakılması gerekliliğini ortaya çıkarmaktadır. CC'de hem "ocht" hem de "oct" biçiminde yazılan sözcük Farsça "wagt"1n karşıllğı olarak saat sözcüğüyle birlikte verilmiş; diğer kullanımda ise "as octi" (aş okt1) örneğiyle gösterilmiştir (Argunşah ve Güner, 2015, s.199). Çağdaş lehçelerden Kazak Türkçesindeki "ara sıra, bazı bazı, arada bir" anlamlarına gelen "oqtın oqtın" ikilemesi (Oraltay, Yüce, ve Pınar, 1984， s.210) sözcükle anlam bakımından yakın görünmektedir. Diğer taraftan Kıpçak grubu lehçelerinde Arapça kelimelerin sözcük başı "v" konsonantının o ö vokallerine dönüşerek ses değişimine uğradığı bilinmektedir: vebal > obal, vefa > opa, vekil > ökil (Kazak Türkçesi), vakit > ubakıt (Kırgız Türkçesi) vd. Buradan hareketle "vakit" sözcügüunün vakit>okt gibi bir dönüşüme doğrudan uğraması izaha muhtaç görünmektedir. Diğer bir ifadeyle "vakit" sözcügünün "okt" durumuna gelme sürecinde ara değişimleri örneklendiren herhangi bir bulguya rastlanmamıştır. Fonetik bakımından bu şekilde doğrudan bir değişim pek de mümkün görünmemektedir. Yine bugünkü Kazak lehçesinde vakit sözcüğü "waqıt" şekliyle kullanılmakta herhangi bir fonetik değişikliğe uğramadığı görülmektedir.

Türkçe başka bir dilden alıntı sözcük alırken sözcüğü ya doğrudan herhangi bir değişikliğe uğratmadan ya da birtakım fonetik değişikliklere uğratarak Türkçeye dahil etmiştir; "asker, alem, aziz, birader, cüsse, efrad, eşkıya, ganimet, harita, ihmal, imsak, kafa, vatan" gibi pek çok sözcük herhangi fonetik bir değişikliğe uğramadan doğrudan dilimize girmiştir. Bunun yanında "bûstan $>$ bostan, came-şuy > çamaşır, cehaz > çeyiz, çâr-sû > çarşı, dest-gah > tezgah, kleid > kilit, matbah > mutfak, nerd-ban > merdiven, penc-şenbe $>$ perşembe, skala $>$ iskele" gibi pek çok 
sözcük de fonetik değişikliğe uğramış ve Türkçeye bu şekilde girmiştir. Dolayısıyla fonetik değişikliğe uğrayarak Türkçe söyleyişe uygun hale getirilmiş sözcüklerin alınan dildeki orijinal halleriyle aynı anda kullanımı söz konusu değildir. Yani bir metinde hem "matbah" hem de "mutfak" sözcükleri bir arada kullanılmamıştır. Sadece "akl akı1l, dîvâr divâr, düşmen düşman, fakîr fakir, ferişteh ferişte, fursat $\sim$ firsat, hasm $\sim$ hasım, hayr hayır, hisab hesab, ömr ömür, şükr ş̧ükür, tohm tohum” gibi bazı Arapça ve Farsça sözcükler yazma eserlerde ikili kullanıma sahip olup bu durum da müstensihin tercihi ve imla ile ilgili bir durumdur. Görüldügü gibi bu örneklerde "vakt okt" örneğindeki gibi sözcüğün birkaç fonetik değişiklik geçirme durumu söz konusu değildir. Bu durumda Eski Anadolu Türkçesi dönemi metinlerinde hem "oht/okt/ok" hem de "vakt/vaht/vakıt/vahıt" sözcüklerinin aynı metin içinde birlikte hatta yan yana kullanılmış olması bu iki sözcüğün birbirinden farklı sözcükler olarak değerlendirilmesi bakımından daha makul ve mantıklı görünmektedir. "vakt" sözcüğü bu dönemin hemen hemen her eserinde ve daha sonraki dönemlerde görülmekte dolayısıyla sözcügün Arapça "vakt" sözcügünden geldiği iddiası zayıflamaktadır. Her iki sözcüğün de "zaman, vakit, an" anlamları taşıması, metin içinde bu anlamlarda kullanılması onları birbirine yaklaştırmış ve aynı sözcük olduğu kanaatini oluşturduğu görülmektedir. Sonuç olarak "oht” sözcüğünün Arapça "vakt" sözcüğüyle aynı sözcük olduğu ya da "vakt" sözcüğünden fonetik değişimlere uğrayarak yeni bir şekil aldığı iddiası zayıf bir görüş olarak değerlendirilmelidir.

\section{Sözcüğün Eski Türkçe “öd” Sözcüğüyle İlgisi:}

Eski Türkçe Döneminde "an; huzur; saat, devir, mevsim" (Gabain, 2003, s.164-289) gibi anlamlara gelen "öd öt" sözcüğü Göktürk Yazttlarında ve Uygur metinlerinde geçmektedir.

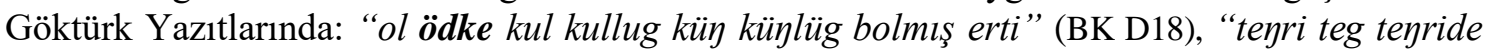
bolmıs türük bilge kagan bu ödke olurtum" (KT G1), "b'ödke körügme begler gü yayıltaçı siz" (KT G11), "öd teyri aysar kişi oglı kop ölgeli törimiş" (KT K 10) gibi satırlarda "öd” sözcüğü "zaman" anlamında kullanılırken "Ögüğ yoğuru sü yortp tünli künli yiti ödüsske subsuz keçdim" (BK GD) cümlesinde "ödüş" sözcüğünün anlamı "tam gün, 24 saat" olarak verilmiştir (Tekin, 1998, s. 108). Clauson da "öd" sözcüğünün anlamını: zaman, zamanda bir an, zamanda bir periyot" olarak vermekte aynı zamanda sözcüğün mevsim (sezon), saat ve yıl gibi kullanımlara da karşıllk geldiğini örneklemiştir (Clauson, 1972, s. 35). Eski Türkçe döneminin bir diğer devresini oluşturan Uygur metinlerinde de "öd/üd" sözcüğü "zaman, an, süre" gibi anlamlarda geçmektedir: "küntüz altı üdde bir-tin singar/gündüz altı zamanda sağdaki” (AY III. Kt. 3a/13), "ïdki ondın singar-kl alk-u kamağ burkan/zamana ait on yöndeki bütün (iki.) Buda" (AY III. Kt. 3b/1), "kin keligm-e üd-lerte yavlak tüş/ilerde, gelecek olan zamanlarda kötü karşılı̆̆l”" (AY III. Kt. 6b/14), "Yitinç ödsüz kolusuz slgurmak." "Yedincisi: vakitsiz toplamak." (Maitri 32,1)" (Şenaysoy, 2016, s. 54), "biş çöbik yavlak öd/Şu beş kötü devirde" (Şenaysoy, 2016, s.75), "ol ödün kayı kan bu ötüg sav esidip näy kiginç berü umadı." (IKPÖXV.7.): O anda babası han bu rica sözlerini isitince hiç cevap vermedi." (Baran, 2008, s. 43). Karahanlı Türkçesi döneminin önemli eserleri olan Divânu Lugâti't-Türk, Kutadgu Bilig'de “öd” sözcügünün kullanıldığını görüyoruz: DLT'de “öd keçer kişi tuymas/zaman geçer insan duymaz”" (Atalay, 1985, s. 40-41), "tüş ödi" șeklindeki kelime grubuna "konulacak zaman" anlamı verilmiştir (Atalay, 1985, s.330); KB'de "Öd kün yawa kıl- (6431) zamanı boşa harcamak”, "Ödü kel- (554) zamanı gel-", "Ödü yetil- (1099) vakti gel-“, "Ödine küd-(3530) vaktini bekle- " (Eker ve Kök, 2019, s. 236).

Peki Eski Türkçe metinlerinde görülen "öd” sözcügü Anadolu sahasına taşınmış olabilir mi? Gülensoy "ot” sözcügünü "hlk. zaman, vakit” anlamında verirken sözcüğün "öd” sözcügüüden geldiğine işaret etmiş ve Uşak yöresinde kullanılan "akşam otu" sözcüğünü bu duruma örnek olarak vermiştir (Gülensoy, 2007, s.635). Eren ise "öd” sözcügünün Anadolu ağızlarında bu şekliyle bulunamayacağını buna sebep olarak da Eski Türkçedeki /d / sesinin Batı Türkçesinde /y/ sesine değişmesini gösterir (Eren, 2010, s. 262). Eski Anadolu Türkçesindeki "oht/okt/ok" sözcüğünün "öd" sözcügüyle ilgisinin olması imkansız olmamakla birlikte ciddi bir etimolojik izah ve konuyla ilgili Anadolu sahasındaki örneklerin daha fazla örneklenmesi gerekmektedir. Gerek Eski Anadolu Türkçesinin daha eski dönemlerine ait eserlerin ortaya çıkması gerekse 
Anadolu ağızlarında konuya örnek sözcüklerin derlenmesi “öd” sözcüğünün "oht/okt/ok" sözcükleriyle ilgisini netleştirecektir. Anadolu ağızlarındaki "aşamotu, aşamutu" gibi kullanımların "öd” sözcügüüle ilgisinin göz ardı edilmemesi kanaatindeyiz.

\section{Sözcüğün Bir İkilemeden Gelmiş Olması:}

"oht/okt” sözcüğünün öncesinde bir ikileme daha sonra bazı fonetik değişikliklerle bir sözcük haline gelmesi de ihtimallerden biridir. Burada bu olasıllı̆̆ güçlendiren en önemli malzemelerden biri sözcüğün "ok" biçiminin "ol, şol” gibi işaret sıfatlarıyla kullanıldığında; olok dem, olok saat, şolok dem gibi sadece zaman bildiren ifadelerle birlikte kullanılmasıdır.

Divanü Lugati’t-Türk’te geçen “yazok yazuk” sözcüğü; sonbaharda baharatla karıştırıllıp doğranan ve ilkbaharda yenen et (Ercilasun ve Akkoyunlu, 2014, s.964) olarak açıklanmıştır. Kaşgarl1, sözcügün açıklamasında "yaz ok yi sözünden alınmıştır, onu sadece baharda ye..." diyerek "bahar zamanı, bahar vakti" anlamında "ok" sözcüğünü kullanmıştır (Ercilasun ve Akkoyunlu, 2014, s.354). Ettuhfetü'z-Zekiye yazarı ok edatını -kaç/-keç zarf-fiil ekine muadil tutuyor -kan/-ken eki ile yapılmış ve şahıs ekleri ile genişletilmiş isim-fiillerden sonra gelen ok'un, bunları zaman zarfı haline getirdiğini yazıyor: ketkenim ok "gittiğim zaman", kelgenimiz ok "geldiğimiz zaman", alganınız ok "aldığınız zaman" yigeni ok "yediği zaman" vb. (Korkmaz, 2005, s.106). Dolayısıyla bu açıklamalardan yola çıkılarak "ok" sözcügünün "zaman, vakit" gibi anlamlara geldiği sonucuna ulaşılabilir.

"oht” sözcüğüyle ilgili ilk çalışmanın sahibi Canpolat, sözcüğün aslının “oktın” olduğunu burada "ok" ve "tın" sözcüklerinin birleşerek bir sözcük oluşturduğunu görüşünü savunur (Canpolat, 1988, s.182). "tın" sözcügü Eski Uygur Türkçesinde; "can, ruh, cevher, madde, nefes" anlamlarına gelmektedir (Caferoğlu, 2015, s.237). Yine DLT'de sözcügün anlamı "nefes, ruh" olarak verilmiştir (Ercilasun ve Akkoyunlu, 2014, s.877). Dolayısıyla sözcüğün yakın anlamlı sözcüklerle kurulmuş "ok tın" şeklinde bir ikileme olma olasılığı mevcuttur. Eski Anadolu Türkçesi metinlerinde "ok dem, ok saat" kullanımlarının daha eskicil kullanımlar olduğu düşünülürse Türkçe "tın" sözcüğü yerine "zaman, vakit, an" anlamı taşıyan Arapça "saat", Farsça "dem" sözcükleri ikame edilmiştir. Bu durum da Türkçenin ikileme oluşturma yöntemlerinden biri olan aynı anlama gelen sözcüklerin biri Türkçe biri yabancı dilden alınma biçimine (hasta sayrı, sorgu sual, kılık kıyafet, sağ salim, köşe bucak vd.) uymaktadır. Bu yaklaşım da sözcüğün kökenine dair mantıklı bir yaklaşım olarak değerlendirilebilir.

\section{SONUÇ}

Bu çalışmada "oht" sözcüğüyle ilgili dil kuralları çerçevesinde birtakım olasılıklar ortaya konulmaya çalışıldı. Sözcügün sadece Eski Anadolu Türkçesi metinlerinde var olması, Arapça "vakt" sözcügüyle hem anlamsal hem de biçimsel olarak benzeşmesi, birbiri yerine kullanılabilmesi, Arap alfabesiyle "vakt" ve "oht/okt" sözcüklerinin yazımlarının birbirine benzemesi, Eski Türkçede Eski Anadolu Türkçesindeki biçimiyle kullanımıyla bire bir aynı olan örneklerin bulunmaması, ölçünlü Türkçe içerisinde kullanılmaması gibi sorunlar sözcüğün izahını güçleştirmektedir. Diğer taraftan sözcüğün bugünkü Türk lehçelerinden Kazak Türkçesinde "oqtın oqtın" şeklinde ve anlamsal bakımından "zaman, vakit, an" sözcüklerine yakın kullanılması yine Anadolu ağızlarında hâlâ aynı anlamıyla yaşıyor olması sözcüğün devamlılığı noktasında önem arz etmektedir. Eldeki tüm örnekler ve olasılıklar göz önüne alındığında sözcüğün Türkçe olduğunu, Türkçe bir yapının fonetik birtakım değişikliklere uğradığı kanısındayız. Çünkü sözcüğün "ol ok, şol ok" gibi kullanımlarından görüleceği üzere "k” sesli biçimi aslî, birincil biçimi olmalıdır. Daha sonra "k"nın sızıcılaşması neticesinde $/ \mathrm{h} / \sim / \mathrm{h} /$ sesleri ortaya çıkmıştır. Dolayısıyla; "ok dem, ok saat" gibi kullanımlar "ok tın" kullanımından hemen sonraki süreç olup daha sonra $/ \mathrm{k} />/ \mathrm{h} /$ sizıcılaşması olayıyla sözcük "oh" biçimine dönmüş olmalıdır. "oḩ tın, oh tun" gibi biçimlerin de kullanıldığ niteliktedir. XIV-XV. yüzyıl yazarlarının "ohtın” sözcügünü yanlış ayırarak "oht” biçiminde bir 
sözcük ortaya çıkardıklarını iddia eden Canpolat, "oht+1n" daki $\{+\operatorname{In}\}$ ekinin araç durum eki olmadığını belirtir (Canpolat, 1988, s.182). Şu durumda sözcügün Arapça "vakt" sözcügüyle biçim bakımından benzeşmesi ve anlam bakımından yakın olması onun Arapça "vakt" sözcüğünden değiştiği kanaatini oluşturmuştur fakat bu durum yukarıda izah edildiği gibi pek mümkün görünmemektedir.

Sözcük hakkında kesin bir hükme varılması alanda yapılacak yeni çalışmalara ve ortaya çıkacak yeni belgelere bağlıdır. Türkçenin farklı dönemlerinde ve günümüzde sözcükle ilgili tespit edilebilecek yeni bulgular sözcüğün kökeni ve işlevi hakkında aydınlatıcı olacaktır. Ancak sözcüğün imla, biçim, fonetik ve anlamsal benzerlik, Eski Anadolu Türkçesi Dönemine ait özel durumlar (etnik yapı, Asyalı müellifler ve müstensihler, siyasi çeşitlilik) gibi pek çok özellik göz önüne alınarak değerlendirilmesi araştırmacıları daha doğru ve sağlıklı sonuçlara götürecektir.

\section{KISALTMALAR}

$$
\begin{array}{ll}
\text { AY } & \text { : Altun Yaruk } \\
\text { BK } & : \text { Bilge Kağan } \\
\text { CC } & : \text { Codex Cumanicus } \\
\text { D } & : \text { Doğu } \\
\text { DAH } & \text { : Dastan-1 Ahmed Haramî } \\
\text { DLT } & : \text { Divânu Lugâti’t-Türk } \\
\text { DS } & : \text { Derleme Sözlüğü } \\
\text { DTCF } & : \text { Dil Tarih ve Coğrafya Fakültesi } \\
\text { FN } & : \text { Ferheng-nâme } \\
\text { G } & : \text { Güney } \\
\text { GD } & : \text { Güneydoğu } \\
\text { HN } & : \text { Hurşid-nâme } \\
\text { IN } & : \text { Işk-nâme } \\
\text { IKPÖ } & : \text { İyi ve Kötü Prens Öyküsü } \\
\text { K } & : \text { Kuzey } \\
\text { KB } & : \text { Kutadgu Bilig } \\
\text { KD } & : \text { Kelile ve Dimne } \\
\text { KG } & : \text { Kitab-1 Güzide } \\
\text { Kt. } & : \text { Kitap } \\
\text { KT } & : \text { Kül Tigin } \\
\text { MŞ } & : \text { Melhame-i Şemsiyye } \\
\text { RE } & : \text { Rahatü’l-Ervah } \\
\text { SN } & : \text { Süheyl ü Nevbahar } \\
&
\end{array}
$$


ŞL : Şamilü'l-Luga

TET : Tezkiretü'l Evliya Tercümesi

vd. : Ve diğerleri

YED : Yunus Emre Divanı

\section{KAYNAKÇA}

Akar, A.(2018). Oğuzların Dili Eski Anadolu Türkçesine Giriş. İstanbul: Ötüken.

Aksoy, Ö. A., Dilçin, D. (2009). Tarama Sözlüğü 8 Cilt. Ankara: TDK.

Argunşah, M., Güner, G. (2015). Codex Cumanicus. İstanbul: Kesit.

Atalay, B. (1985). Divanü Lûgat-it Türk Tercümesi. Ankara: TDK.

Baran, B. (2008). Eski Türkçeden Anadolu Ağızlarına Ulaşan Bazı Kelimeler. Türk Dünyası İncelemeleri Dergisi / Journal of Turkish World Studies, Cilt: VIII, Say1 1, ss. 41-47.

Caferoğlu, A. (2015). Eski Uygur Türkçesi Sözlüğü. Ankara: TDK.

Cahen, C. (1994). Osmanlılardan Önce Anadolu’da Türkler, İstanbul: E Yayınları.

Canpolat, M. (1998). "Oht=Zaman Sözcüğü Üzerine”. Ankara Üniversitesi Dil ve Tarih-Coğrafya Fakültesi Dergisi Cilt 32, Say1 1-2 ss. 177-183.

Clauson, S. G. (1972). An Etymological Dictionary of Pre-Thirteenth-Century Turkish, Oxford: Clarendon Press.

Derleme Sözlüğü. (2009). 6 Cilt. Ankara: TDK.

Dilçin, C. (2016). Mesud bin Ahmed Süheyl ü Nevbahar İnceleme-Metin-Sözlük. Ankara: AKMB.

Eker, Ö., Kök, A. (2019). Kültürel Dil Bilim Bağlamında Kutadgu Bilig Metaforları. Mediterranean Journal of Humanities, mjh.akdeniz.edu.tr, IX/2 (2019) ss. 225-242, DOI: 10.13114/MJH.2019.487.

Ercilasun, A. B. ve Akkoyunlu, Z. (2014). Kaşgarlı Mahmud Divanu Lugati’t Türk Giriş-MetinÇeviri-Notlar-Dizin. Ankara: TDK.

Eren, H. (2010). Sirça Köşkte. Ankara: TDK.

Gabain, A.Von (Çev.Mehmet Akalın). (2003). Eski Türkçenin Grameri. Ankara: TDK.

Gülensoy, T. (2011). Türkiye Türkçesindeki Türkçe Sözcüklerin Köken Bilgisi Sözlüğü 2 Cilt. Ankara: TDK.

Gülsevin, G., Boz, E. (2010). Eski Anadolu Türkçesi. Ankara: Gazi.

Kanar, M. (2011). Eski Anadolu Türkçesi Sözlüğü. Ankara: Say.

Korkmaz, Z. (2013). Türkiye Türkçesinin Temeli Oğuz Türkçesinin Gelişimi. Ankara: TDK.

Korkmaz, Z. (2005). Türk Dili Üzerine Araştırmalar I.Cilt. Ankara: TDK.

Kilisli Rifat ve Veled Çelebi. (1923). Ferhengname-i Sa'di Tercümesi. İstanbul: Matbaa-i Amire. 
Oraltay, H., Yüce, N., Pınar, S. (1984). Kazak Türkçesi Sözlüğü. İstanbul: Türk Dünyas1 Araştırmaları Vakfi.

Ölmez, M. (1991). Altun Yaruk III. Kitap (= 5. Bölüm). Ankara: Türk Dilleri Araştırmaları Dizisi.

Şenaysoy, S. (2016). Eski Türkçede Sayılar. Eskişehir Osmangazi Üniversitesi Sosyal Bilimler Enstitüsü Türk Dili ve Edebiyatı Anabilim Dalı Türk Dili Bilim Dalı Yayınlanmamış Yüksek Lisans Tezi. Eskişehir.

Tekin, T. (1998). Orhon Yazıtları Kül Tigin, Bilge Kağan, Tonyukuk. İstanbul: Simurg. 